\title{
Effects of sire line, birth weight and sex on growth performance and carcass traits of crossbred pigs under standardized environmental conditions
}

\author{
Kathrin Elbert $^{1}$, Neal Matthews ${ }^{2}$, Ralf Wassmuth ${ }^{3}$, and Jens Tetens ${ }^{1}$ \\ ${ }^{1}$ Department of Animal Sciences, Division of Functional Breeding, Georg-August University Göttingen, \\ Burckhardtweg 2, 37077 Göttingen, Germany \\ ${ }^{2}$ Pig Improvement Company (PIC) North America, 100 Bluegrass Commons Blvd., Ste. 2200, Hendersonville, \\ TN 37075, USA \\ ${ }^{3}$ Faculty of Agricultural Sciences and Landscape Architecture, Division Animal Breeding, \\ University of Applied Sciences Osnabrück, Am Kruempel 31, 49090 Osnabrück, Germany
}

Correspondence: Kathrin Elbert (k.elbert@hs-osnabrueck.de)

Received: 27 March 2020 - Accepted: 3 September 2020 - Published: 3 November 2020

\begin{abstract}
A variety of available terminal sire lines makes the choice of terminal sire line complex for the pig producer. Higher birth weights are important for subsequent growth performance and selection for this trait is also necessary in sire lines. The aim was to investigate the effect of sire line, birth weight and gender on growth performance, carcass traits and meat quality. In total 3844 crossbred pigs from Camborough Pig Improvement Company (PIC) dams matched with either a Synthetic (A) or Piétrain (B) sire line were used. Pigs from line A grew faster $(p<0.01)$, showed higher feed intake $(p<0.01)$ and reached a higher final body weight $(p \leq$ $0.01)$, but they had a similar efficiency $(p=0.179)$. Leaner carcasses and heavier primal cuts $(p<0.001)$ were observed in pigs from line B. Carcasses from pigs sired by line A had higher meat quality $(p<0.001)$. Males had a higher growth rate $(p \leq 0.05)$ but had a poorer feed efficiency $(p<0.01)$. Heavier birth weight pigs and females had leaner, higher value carcasses with heavier primal cuts $(p<0.001)$ compared to middle and low birth weight females or males. Sire line by sex interactions was significant for growth $(p \leq 0.05)$ and carcass traits $(p<0.001)$. Interaction between sire line and birth weight classes were only detected for loin depth $(p<$ 0.01 ). Line A is preferable if the numbers of fatting pigs per fattening place and year should be improved, and line $\mathrm{B}$ is an option to increase leanness and carcass primal cuts.
\end{abstract}

\section{Introduction}

Production efficiency of fattening pigs in terms of average daily gain, feed efficiency and carcass composition is a heritable trait complex (Aymerich et al., 2019; Cámara et al., 2016; Latorre et al., 2003; Serrano et al., 2008), for which considerable heterosis effects are harnessed in crossbreeding schemes (García-Casco et al., 2012; Katoele et al., 2002; Luo et al., 2018). In commercial pig production, the dam line is usually fixed, and as a consequence of artificial insemination (AI) sire line selection is flexible. According to the BMEL (2019), currently nine pig breeding companies are operating in the European Union. The fact that each company improves and offers at least one or two basic sire lines, and selects these in different ways, leads to a variety of sire lines. This results in a complex choice for the pig producers.

Individual piglet birth weight is important for subsequent growth performance (Fix et al., 2010; Vázquez-Gómez et al., 2020). Sire line impacted piglet birth weight (Vermeulen et al., 2016); hence, a selection of purebred sires on birth weight is useful (Dufrasne et al., 2013), and the importance of sire lines in breeding programs is increasing (Dodenhoff et al., 2019). Regarding gender, controversial results with respect to growth performance can be found (Franco et al., 2014; Lee et al., 2019; Morales et al., 2011). Hence, a closer ex- 
amination of sire line effects on offspring birth weight and of the implications of gender for further performance is needed.

Several studies have analyzed offspring performance in the period of fattening with various sire lines, in terms of variables such as feed composition, different breeding values and selection strategies, or various possibilities of male castration (Cámara et al., 2016; Cilla et al., 2006; De Cuyper et al., 2019; Gilleland et al., 2019; Lowell et al., 2019; Morales et al., 2011). Against this background, an integrated view on productivity from birth to finishing seems necessary. Hence, in the current study, different sire lines where mated to the same sow genotype in an integrated production system. The aim was to investigate the effect of sire line, birth weight, and gender on growth performance, carcass and meat quality traits.

\section{Materials and methods}

\subsection{Ethics statement}

All work was done in accordance with the German legal and ethical requirements for appropriate animal procedures. This study was approved by the institutional animal care and use committee of Göttingen University under file number E819.2.1 Husbandry and diets

A total of 3844 crossbred pigs divided into four batches resulted from the mating of 337 dams (Camborough Pig Improvement Company, PIC, a crossbred sow between Large White and Landrace, F1) to 35 terminal sires (sire line A: 15 boars; sire line B: 20 boars). Line A was the PIC337 (PIC, 100 Bluegrass Commons Blvd, Ste 2200, Hendersonville, TN 37075), which is a closed composite population for over 40 years that includes genes of Duroc, Landrace, Large White and Piétrain descent and has been selected for lean efficient growth and carcass value. A pure Piétrain population was Line B, the PIC408 (PIC, 100 Bluegrass Commons Blvd, Ste 2200, Hendersonville, TN 37075), which is selected for carcass value, growth and efficiency. The batches were organized over four consecutive fattening cycles between May 2018 and February 2019. All pigs were born, reared and fattened under the same standardized environmental conditions in a commercial closed herd system. The farm was approximately $50 \mathrm{~km}$ west of Leipzig, Germany, and consisted of 3100 fattening places. At birth, all pigs received an individual transponder ear tag. On their third day, males were given an intramuscular injection of meloxicam (Metacam ${ }^{\circledR}$, $5 \mathrm{mg} \mathrm{mL}^{-1}$ ) and were surgically castrated. At $71.9 \pm 1.1$ days of age, pigs were regrouped into the common finishing barn. All pigs were placed in groups of 40 to 64 pigs per pen according to the genetic sire line and gender. Pens were stocked to the same number of pigs per square meter and pig size. Pigs were selected for slaughtering by an estimation of the individual body weight. The weight estimation was determined by a pen reference group, consisting of two pigs, which had reached the final body condition. These pigs were weighed
Table 1. Composition and nutrient content of the pig diets (\%, asfed basis, unless otherwise indicated).

\begin{tabular}{|c|c|c|c|c|}
\hline & \multicolumn{4}{|c|}{ Fattening phase (d) } \\
\hline & 0 to 10 & 11 to 30 & 31 to 69 & 70 to harvest \\
\hline \multicolumn{5}{|l|}{ Ingredient $^{\mathrm{a}}$} \\
\hline Wheat & 21.39 & 10.71 & 8.03 & 4.58 \\
\hline Barley & 16.70 & 10.50 & 8.56 & 7.76 \\
\hline Corn-Cob mix & 23.61 & 31.04 & 32.51 & 34.65 \\
\hline Molasses chip & 2.77 & 3.18 & 3.17 & 3.17 \\
\hline Soybean meal & 14.60 & 11.93 & 10.58 & 7.68 \\
\hline Elan 1480 & 5.86 & 5.09 & 4.89 & 4.88 \\
\hline Wheat starch & 7.81 & 13.04 & 15.64 & 18.22 \\
\hline Wheat slop & 3.04 & 6.09 & 6.08 & 7.29 \\
\hline Rye slop & 4.21 & 8.43 & 10.54 & 11.78 \\
\hline \multicolumn{5}{|l|}{ Nutrient content ${ }^{b}$} \\
\hline ME, Pig $\left(\mathrm{MJ} \mathrm{kg}^{-1}\right)$ & 13.02 & 13.08 & 13.07 & 13.05 \\
\hline Crude protein & 17.17 & 16.86 & 16.47 & 15.67 \\
\hline Crude fiber & 3.28 & 3.26 & 3.22 & 3.18 \\
\hline Crude fat & 2.63 & 3.01 & 3.07 & 3.20 \\
\hline Crude ash & 5.99 & 5.64 & 5.52 & 5.45 \\
\hline Lysine & 1.13 & 1.06 & 1.02 & 0.97 \\
\hline Methionine, Cysteine & 0.67 & 0.65 & 0.63 & 0.61 \\
\hline Tryptophan & 0.21 & 0.20 & 0.19 & 0.18 \\
\hline Threonine & 0.66 & 0.65 & 0.63 & 0.60 \\
\hline Calcium & 0.83 & 0.74 & 0.72 & 0.72 \\
\hline Phosphorous & 0.56 & 0.57 & 0.57 & 0.58 \\
\hline Sodium & 0.25 & 0.24 & 0.25 & 0.26 \\
\hline Vitamin A (IE) & 6302 & 5470 & 5258 & 5248 \\
\hline Vitamin D (IE) & 1547 & 1343 & 1291 & 1288 \\
\hline Vitamin E (mg) & 97 & 85 & 81 & 81 \\
\hline Phytase (FYT) & 688 & 597 & 574 & 572 \\
\hline Lysine $10^{-1} \mathrm{MJ} \mathrm{ME}$, pig & 0.87 & 0.81 & 0.78 & 0.74 \\
\hline Lysine: Met + Cys & $1: 0.59$ & $1: 0.61$ & $1: 0.62$ & $1: 0.63$ \\
\hline Lysine: Tryptophan & $1: 0.19$ & $1: 0.19$ & $1: 0.19$ & $1: 0.18$ \\
\hline Lysine: Threonine & $1: 0.59$ & $1: 0.61$ & $1: 0.62$ & $1: 0.63$ \\
\hline
\end{tabular}

${ }^{\text {a }}$ Represented as \% of $100 \%$ dry matter. ${ }^{b}$ Represented as $\%$ of $88 \%$ dry matter.

individually with an animal scale. Based on this reference group the other pigs were selected and their weights were estimated. Pen-wise and at each selection day for slaughtering this process step was repeated by the same person. Pens had a slatted floor and cross feeder. Space allowance was $1 \mathrm{~m}^{2}$ per pig. Pigs had ad libitum access to water. They were fed with a sensor feeding system that supplied diets appropriate to the fattening period. Table 1 presents the compositions of the diets. The average ambient temperature during the fattening period was $22.7 \pm 5.1^{\circ} \mathrm{C}$. Temperature was controlled and adjusted according to the outside environment temperature by means of an automatic indoor heating and ventilation system.

\subsection{Growth performance}

Individual birth weights $\left(\mathrm{BW}_{\text {birth }}\right)$ were recorded within 12 $24 \mathrm{~h}$ after birth. After regrouping in the fattening barn, all pigs were weighed by pen, and an average initial body weight per pen was calculated $\left(\mathrm{BW}_{\text {initial }}\right)$. This date was assigned as 
day 0 , the first day of the fattening phase on which feed consumption per pen was recorded. A single day before slaughtering the selected pigs were weighed by pen to calculate the average final body weight $\left(\mathrm{BW}_{\text {final }}\right)$. These data were used to calculate average daily gain (ADG), average daily feed intake (ADFI) and the average feed conversion ratio (FCR) for each pen. The age at slaughter and the hot carcass weight $(\mathrm{HCW})$ were used to calculate the individual net $\mathrm{ADG}\left(\mathrm{ADG}_{\mathrm{net}}\right)$ per pig.

\subsection{Carcass traits}

Pigs were transported approximately $35 \mathrm{~km}$ to the commercial slaughterhouse Tönnies Zerlegungs $\mathrm{GmbH}$, Weissenfels, Germany. Access to feed was stopped $12 \mathrm{~h}$ before slaughter although water was still provided ad libitum. Offspring of both sire lines were slaughtered on the same day. Upon arrival at the slaughterhouse, pigs were rested for $3 \mathrm{~h}$, with access to water. All pigs were slaughtered in accordance with Germany's current regulations on animal welfare and protection for the slaughter process (TierSchIV, 2012). Carcass composition ( $n=3437$ pigs) was determined using Auto-FOM III and composition traits variables included HCW, lean meat (LM), loin depth (LD), back fat thickness (FT), belly weight (BE), belly lean meat percentage (BLM), boneless ham weight $(\mathrm{BH})$, loin weight (LO), boneless loin weight (BLO) and boneless shoulder weight (BSH).

\subsection{Meat quality}

Investigation of the meat quality was conducted due to $\mathrm{pH}$ measurements, whereby both genotypes were measured at the same slaughter days. The $\mathrm{pH}$ was measured at the M. longissimus dorsi at $45 \mathrm{~min}\left(\mathrm{pH}_{45} \mathrm{~min}\right)$ and $24 \mathrm{~h}\left(\mathrm{pH}_{24} \mathrm{~h}\right)$ post mortem, on the left side of the carcass between the 10 th and 11th rib. The electrode of the $\mathrm{pH} / \mathrm{ORP}$ meter (HI $98160 \mathrm{pH} / \mathrm{ORP}$ meter, HANNA instruments) was calibrated with buffers at $\mathrm{pH}$ of 4 and 7 immediately prior to taking measurements. Based on carcass temperature, the $\mathrm{pH}$ meter was standardized to $40.0^{\circ} \mathrm{C}$ for $\mathrm{pH}_{45}$ min and to $4.0^{\circ} \mathrm{C}$ for $\mathrm{pH}_{24} \mathrm{~h}$. Post mortem, after dressing and recording $\mathrm{pH}_{45}$ min, carcasses were suspended in air and chilled to a temperature of $4.0^{\circ} \mathrm{C}$.

\subsection{Statistical analyses}

Statistical analyses were performed using SAS version 9.4 (SAS Institute Inc., Cary NC, USA). A descriptive analysis (mean, standard deviation, and minimum and maximum values) was carried out with the MEANS procedure. Multivariate analysis of variances were performed by the procedure MIXED with the REML method and using the KenwardRoger adjustment for the degrees of freedom. The Tukey test was used to compare the least-squares means (LSQ means) with the standard error (SE) for each trait. Differences were considered statistically significant at a confidence level of $95 \%$ ( $p \leq 0.05)$. Appropriate two-way interactions between the fixed effects were tested and dropped from the model at a $p$ value of $>0.05$ in the $F$ test. For growth performance traits (ADG, ADFI, FCR, $\mathrm{BW}_{\text {initial }}, \mathrm{BW}_{\text {final }}$ ) pen was considered as the experimental unit, except for $\mathrm{ADG}_{\text {net }}$ and

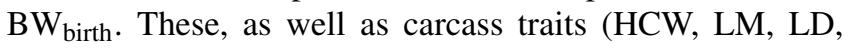
FT, BE, BLM, BH, LO, BLO, BSH) and meat quality traits $\left(\mathrm{pH}_{45}\right.$ min and $\left.\mathrm{pH}_{24} \mathrm{~h}\right)$, were analyzed based on individual measurements per pig. According to the quantiles of the frequency distribution, $\mathrm{BW}_{\text {birth }}(1.45 \pm 0.35 \mathrm{~kg}$, min: $0.38 \mathrm{~kg}$; max: $2.65 \mathrm{~kg}$ ) was divided into three groups $\left(\mathrm{BW}_{\mathrm{Q}}\right)$ : lower $25 \%\left(<1.22 \mathrm{~kg} ; \mathrm{BW}_{\mathrm{Q} 1}\right)$, middle $50 \%(\geq 1.22<1.70 \mathrm{~kg}$, $\left.\tilde{x}=1.46 \mathrm{~kg} ; \mathrm{BW}_{\mathrm{Q} 2}\right)$ and upper $25 \%\left(\geq 1.70 \mathrm{~kg} ; \mathrm{BW}_{\mathrm{Q} 3}\right)$. $\mathrm{BW}_{\mathrm{Q}}$ was used as fixed effect for carcass traits and $\mathrm{ADG}_{\text {net. }}$. Moreover, sire line ( $G=$ Line A, Line B), gender ( $S=$ male, female) and batch $(B=1,2,3,4)$ were used as fixed effects for all observed traits. Pen was used as random effect within sire line and batch $\left(\operatorname{Pen}_{(G \times B)}\right)$ for growth traits. In commercial swine production, typically a defined time allotment for various phases of production is applied and initial age (AI), slaughter age (ASL) and HCW differed significant between the sire lines. Hence, it was adjusted to $72 \mathrm{~d}\left(\mathrm{AI}_{\mathrm{adj}}\right)$, to $173 \mathrm{~d}$ $\left(\mathrm{ASL}_{\mathrm{adj}}\right)$ and to $91 \mathrm{~kg}\left(\mathrm{HCW}_{\mathrm{adj}}\right)$, respectively. In order to correct for age or HCW, these were included as linear covariables. $\mathrm{BW}_{\text {final }}$ was introduced into the models for $\mathrm{ADG}$, ADFI and FCR as a linear covariable. Table 2 contains all used effects that were included in the final models for growth and carcass traits.

\section{Results}

The descriptive statistics of all investigated traits according the sire line are in Table 3. A total of 73 pens were used to calculate growth performance. $\mathrm{ADG}_{\text {net }}$ and carcass traits were based on 3437 carcasses. Overall, $672 \mathrm{pH}_{45} \mathrm{~min}$ and $1895 \mathrm{pH}_{24} \mathrm{~h}$ measurements were collected. The LSQ means according to the sire line are reported in Table 4. Offspring of both sire lines exhibited the same $\mathrm{BW}_{\text {initial }}(p=0.743)$. During the fattening phase, pigs sired by line A grew $48.8 \mathrm{~g} \mathrm{~d}^{-1}$ faster $(p<0.01)$ and reached $16.5 \mathrm{~g} \mathrm{~d}^{-1}$ higher $\mathrm{ADG}_{\text {net }}$ $(p<0.001)$ as compared to pigs sired by line B. A $60 \mathrm{~g} \mathrm{~d}^{-1}$ higher ADFI $(p<0.01)$, but the same feed efficiency as sire line B $(p=0.179)$ was detected at sire line A. These offspring were $3.3 \mathrm{~kg}$ heavier in $\mathrm{BW}_{\text {final }}(p<0.01)$. Based on a $90.0 \mathrm{~kg}$ weight gain at finishing, 6 fewer fatting days were needed. Regarding the carcass traits, $\mathrm{HCW}$ was $1.3 \mathrm{~kg}$ higher for offspring of sire line A based on the same age at slaughtering. Sire line A had $340 \mathrm{~g}$ more BE $(p<0.001)$ but no difference in FT ( $p=0.423$ ) compared to pigs from sire line B. Pigs sired by line B had a leaner carcass with heavier primal cuts $(p<0.001)$. No difference between sire lines ( $p=0.061$ ) was detected for $\mathrm{pH}_{45 \text { min }}$, but offspring sired by line $\mathrm{B}$ had a lower $\mathrm{pH}_{24 \mathrm{~h}}(p<0.001)$. 
Table 2. Final models with the $p$ values of fixed effects, random effects, covariates and interactions for growth traits, carcass traits and meat quality.

\begin{tabular}{|c|c|c|c|c|c|c|c|c|c|c|c|c|}
\hline & \multicolumn{4}{|c|}{ Fixed } & \multirow{2}{*}{$\frac{\text { Random }}{\operatorname{Pen}_{(G \times B)}}$} & \multicolumn{4}{|c|}{ Covariates } & \multicolumn{3}{|c|}{ Interaction } \\
\hline & $G$ & $S$ & $B$ & $\mathrm{BW}_{\mathrm{Q}}$ & & $\mathrm{BW}_{\text {final }}$ & $\mathrm{AI}_{\mathrm{adj}}$ & $\mathrm{ASL}_{\mathrm{adj}}$ & $\mathrm{HCW}_{\mathrm{adj}}$ & $G \times S$ & $G \times B$ & $G \times \mathrm{BW}_{\mathrm{Q}}$ \\
\hline \multicolumn{13}{|c|}{ Growth trait } \\
\hline $\mathrm{BW}_{\text {initial }}$ & 0.743 & 0.495 & 0.245 & 0.366 & 0.166 & & & & & & & \\
\hline $\mathrm{BW}_{\text {final }}$ & ** & *** & *** & $* * *$ & 0.197 & & & & & & & \\
\hline $\mathrm{ADG}_{\mathrm{net}}$ & $* * *$ & $* * *$ & $* * *$ & $* * *$ & $* * *$ & $* *$ & & & & & & \\
\hline ADG & $* *$ & $*$ & $*$ & $* * *$ & $* *$ & $*$ & & & & & & \\
\hline ADFI & ** & $* * *$ & $* * *$ & 0.975 & $* * *$ & $* *$ & $*$ & & & & & \\
\hline FCR & 0.179 & ** & $* * *$ & $* * *$ & 0.840 & & & & & & & \\
\hline Age $_{\text {initial }}$ & $* * *$ & 0.268 & $* * *$ & & & & & & & $* * *$ & & \\
\hline $\mathrm{Age}_{\mathrm{SL}}$ & $* * *$ & *** & $* * *$ & & & & & & & $* *$ & $* * *$ & \\
\hline \multicolumn{13}{|c|}{ Carcass trait } \\
\hline HCW & $* * *$ & $* * *$ & $* * *$ & $* * *$ & & & & $* * *$ & & $* * *$ & $* * *$ & \\
\hline LM & $* * *$ & $* * *$ & $* * *$ & $* * *$ & & & & & $* * *$ & $* * *$ & $* * *$ & \\
\hline LD & $* * *$ & $* * *$ & $* * *$ & $* * *$ & & & & & $* * *$ & $* * *$ & $* * *$ & $* *$ \\
\hline FT & 0.423 & $* * *$ & $* * *$ & $* * *$ & & & & & $* * *$ & $* * *$ & $* * *$ & \\
\hline $\mathrm{BE}$ & $* * *$ & $* * *$ & $* * *$ & $* * *$ & & & & & $* * *$ & $* * *$ & $* * *$ & \\
\hline BLM & $* * *$ & $* * *$ & $* * *$ & $* * *$ & & & & & $* * *$ & $* * *$ & $* * *$ & \\
\hline $\mathrm{BH}$ & $* * *$ & $* * *$ & $* * *$ & $* * *$ & & & & & $* * *$ & $* * *$ & $* * *$ & \\
\hline LO & $* * *$ & $* * *$ & $* * *$ & $* * *$ & & & & & $* * *$ & $* * *$ & $* * *$ & \\
\hline BLO & $* * *$ & $* * *$ & $* * *$ & $* * *$ & & & & & $* * *$ & $* * *$ & $* * *$ & \\
\hline BSH & $* * *$ & $* * *$ & $* * *$ & $* * *$ & & & & & $* * *$ & $* * *$ & $* * *$ & \\
\hline \multicolumn{13}{|c|}{ Meat quality } \\
\hline $\mathrm{pH}_{45} \min$ & 0.061 & 0.239 & $* * *$ & & & & & & 0.862 & & & \\
\hline $\mathrm{pH}_{24 \mathrm{~h}}$ & $* * *$ & 0.444 & $* * *$ & & & & & & $* * *$ & & $* *$ & \\
\hline
\end{tabular}

${ }^{*} p \leq 0.05$. $^{* *} p<0.01 .{ }^{* * *} p<0.001$.

Males grew faster (ADG: 883.37 vs. $847.83 \mathrm{~g} \mathrm{~d}^{-1}, p \leq$ $0.05 ; \mathrm{ADG}_{\text {net }}: 532.64$ vs. $\left.513.11 \mathrm{~g} \mathrm{~d}^{-1}, p<0.001\right)$ and had a higher feed intake (ADFI: 2.31 vs. $2.16 \mathrm{~kg} \mathrm{~d}^{-1}, p<0.001$ ) but were less efficient (FCR: 2.62 vs. $2.51 \mathrm{~kg} \mathrm{~kg}^{-1}, p<$ 0.01) compared to females. Consequently, males reached a higher $\mathrm{BW}_{\text {final }}(115.56$ vs. $111.80, p<0.001)$ and a $2.05 \mathrm{~kg}$ heavier HCW $(p<0.001)$. Females had a better carcass value and were $3.04 \%$ leaner with $2.39 \mathrm{~mm}$ thicker $\mathrm{LD}$ and $396 \mathrm{~g}$ less BE $(p<0.001)$ but had heavier primal cuts $(p<$ $0.001)$. Neither $\mathrm{pH}_{45}$ min nor $\mathrm{pH}_{24} \mathrm{~h}$ were affected by sex $(p \geq 0.05)$. The LSQ means of the significant interactions between sire line and sex are presented in Table 5. Males and females sired by line A did not differ in $\mathrm{ADG}_{\text {net }}$ and ADG $(p \geq 0.05)$. In sire line B a faster growth $(p<0.01)$ and higher feed intake $(p<0.01)$ were detected for males compared to females. HCW of males sired by this line did not differ from males and females of sire line A. Females of sire line B were lighter in HCW compared to all other sex and genotype variations. Regardless of sire line, similar $\mathrm{ADG}_{\text {net }}$, ADG, ADFI, HCW, LM, FT, BLM and BSH between males was observed $(p \geq 0.05)$. Females sired from line B reached heavier $\mathrm{BH}, \mathrm{LO}, \mathrm{BLO}$ and $\mathrm{BSH}$ compared to the other sex and genotype variations.

Growth rate and carcass traits according to the birth weight classes are presented in Table 6. Low birth weight pigs $\left(\mathrm{BW}_{\mathrm{Q} 1}\right)$ had the lowest $\mathrm{ADG}_{\text {net }}$ compared to pigs of the middle $\left(\mathrm{BW}_{\mathrm{Q} 2}\right)$ and the heaviest $\left(\mathrm{BW}_{\mathrm{Q} 3}\right)$ birth weight classes. Pigs in the $\mathrm{BW}_{\mathrm{Q} 3}$ reached the fastest growth rate $(p<0.001)$. Moreover, pigs HCW differed correspondingly among the birth weight groups $(p<0.001)$. Pigs in $\mathrm{BW}_{\mathrm{Q} 1}$ were $4.66 \mathrm{~kg}$ lighter compared to pigs of $\mathrm{BW}_{\mathrm{Q} 2}$ and $5.82 \mathrm{~kg}$ lighter than pigs belonging to $\mathrm{BW}_{\mathrm{Q} 3}$. Fatter carcasses based on a thicker FT and a heavier BE, as well as a lower percentage in $\mathrm{LM}$ and $\mathrm{BLM}$, were found for pigs of $\mathrm{BW}_{\mathrm{Q} 1}$ but not for pigs of $\mathrm{BW}_{\mathrm{Q} 2}$ and $\mathrm{BW}_{\mathrm{Q} 3}(p<0.001)$. Furthermore, birth weight was positively related to the weight of $\mathrm{BH}, \mathrm{LO}, \mathrm{BLO}$ and $\mathrm{BSH}$, and a difference was detected among the $\mathrm{BW}_{\mathrm{Q}}$ $(p<0.001)$. The interaction between $\mathrm{BW}_{Q} \times$ sire line was significant for $\mathrm{LD}(p<0.01)$, in sire line $\mathrm{A}$, similar LD was detected for pigs of $\mathrm{BW}_{\mathrm{Q} 2}$ and $\mathrm{BW}_{\mathrm{Q} 3}(62.79$ vs. $62.98 \mathrm{~mm}$, $p \geq 0.05$ ), whereby all other $\mathrm{BW}_{\mathrm{Q}}$ and genotype variations differed $(p<0.001)$. 
Table 3. Descriptive statistics with number of observations, mean and standard deviation for growth traits, carcass traits, and meat quality according to the sire line.

\begin{tabular}{|c|c|c|c|c|c|c|}
\hline & \multicolumn{3}{|c|}{ Sire line A } & \multicolumn{3}{|c|}{ Sire line B } \\
\hline & $n$ & Mean & SD & $n$ & Mean & SD \\
\hline \multicolumn{7}{|l|}{ Growth traits } \\
\hline $\mathrm{ADG}_{\text {net }}\left(\mathrm{g} \mathrm{d}^{-1}\right)$ & 1597 & 534.10 & 56.55 & 1840 & 517.67 & 52.87 \\
\hline $\operatorname{ADG}\left(\mathrm{g} \mathrm{d}^{-1}\right)$ & 33 & 899.45 & 51.44 & 40 & 835.18 & 88.28 \\
\hline $\operatorname{ADFI}\left(\mathrm{kg} \mathrm{d}^{-1}\right)$ & 33 & 2.29 & 0.21 & 40 & 2.20 & 0.24 \\
\hline FCR $\left(\mathrm{kg} \mathrm{kg}^{-1}\right)$ & 33 & 2.53 & 0.18 & 40 & 2.60 & 0.20 \\
\hline $\mathrm{BW}_{\text {initial }}(\mathrm{kg})$ & 33 & 27.17 & 2.82 & 40 & 27.80 & 2.38 \\
\hline $\mathrm{BW}_{\text {final }}(\mathrm{kg})$ & 33 & 115.93 & 5.11 & 40 & 112.29 & 6.04 \\
\hline $\operatorname{age}_{\text {initial }}(\mathrm{d})$ & 1597 & 71.69 & 1.03 & 1840 & 72.14 & 1.12 \\
\hline $\operatorname{age}_{S L}(d)$ & 1597 & 171.65 & 5.87 & 1840 & 174.30 & 5.76 \\
\hline \multicolumn{7}{|l|}{ Carcass traits } \\
\hline HCW (kg) & 1597 & 91.50 & 8.51 & 1840 & 90.07 & 8.11 \\
\hline $\mathrm{LM}(\%)$ & 1597 & 59.74 & 3.26 & 1840 & 60.45 & 3.37 \\
\hline $\mathrm{LD}(\mathrm{mm})$ & 1597 & 62.68 & 4.35 & 1840 & 66.50 & 4.88 \\
\hline FT (mm) & 1597 & 14.03 & 2.71 & 1840 & 13.83 & 2.66 \\
\hline $\mathrm{BE}(\mathrm{kg})$ & 1597 & 13.27 & 1.67 & 1840 & 12.67 & 1.62 \\
\hline BLM (\%) & 1597 & 57.27 & 4.20 & 1840 & 58.16 & 4.38 \\
\hline $\mathrm{BH}(\mathrm{kg})$ & 1597 & 17.47 & 1.63 & 1840 & 17.82 & 1.60 \\
\hline $\mathrm{LO}(\mathrm{kg})$ & 1597 & 10.98 & 1.06 & 1840 & 11.04 & 1.02 \\
\hline $\mathrm{BLO}(\mathrm{kg})$ & 1597 & 6.86 & 0.75 & 1840 & 7.05 & 0.74 \\
\hline BSH (kg) & 1597 & 8.65 & 0.74 & 1840 & 8.59 & 0.71 \\
\hline \multicolumn{7}{|l|}{ Meat quality } \\
\hline $\mathrm{pH}_{45} \min$ & 271 & 6.51 & 0.27 & 401 & 6.55 & 0.23 \\
\hline $\mathrm{pH}_{24 \mathrm{~h}}$ & 872 & 5.43 & 0.14 & 1023 & 5.39 & 0.14 \\
\hline
\end{tabular}

\section{Discussion}

Higher ADG was observed for pigs sired by sire line A, which is a reason for the heavier $\mathrm{BW}_{\text {final }}$ at a fixed slaughter age and may enable more pigs per fattening place and year. This is in line with several other studies applying the same approach (Aymerich et al., 2019; Cámara et al., 2016; Lee et al., 2019; Serrano et al., 2008), in which differences between 2 and $6 \mathrm{~kg}$ for $\mathrm{BW}_{\text {final }}(p \leq 0.05)$ and 41 and $152 \mathrm{~g} \mathrm{~d}^{-1}$ for ADG $(p \leq 0.05)$ among crossbred pigs were observed. It is to be expected that the higher ADFI for pigs sired by line A is linked to the faster growth rate of these offspring. This assumption is generally in line with Kavlak and Uimari (2019) and Labroue et al. (1997), who reported a positive correlation between feed consumption per visit and growth rate. A greater emphasis on growth in line $\mathrm{A}$ in competition with line B is presumed. As a consequence of faster growth, a heavier belly weight and a fatter carcass of crossbreeds sired by line A were detected. According to Kavlak and Uimari (2019), a positive genetic correlation between ADFI and back fat thickness ( $r=0.60-0.72)$ does exist. Consequently, pigs consuming more feed tended to gain more fat. A limited protein disposition capacity of pigs sired by line A with respect to the high feed intake could provide an explanation for the fat accumulation in the carcass and is generally in agree-
Table 4. LSQ mean (with SE as index) for growth traits, carcass traits and meat quality according to the sire line.

\begin{tabular}{|c|c|c|}
\hline & \multicolumn{2}{|c|}{ Sire line } \\
\hline & A & B \\
\hline \multicolumn{3}{|l|}{ Growth traits } \\
\hline $\mathrm{BW}_{\text {jnitial }}^{1}(\mathrm{~kg})$ & $27.61_{0.53}$ & $27.36_{0.41}$ \\
\hline $\mathrm{BW}_{\text {final }}^{2}(\mathrm{~kg})$ & $115.34_{0.84}^{\mathrm{a}}$ & $112.03_{0.73}^{\mathrm{b}}$ \\
\hline $\mathrm{ADG}_{\text {net }}\left(\mathrm{g} \mathrm{d}^{-1}\right)$ & $531.11_{3.09}^{\mathrm{a} .04}$ & $514.65_{2.93}^{\mathrm{b}}$ \\
\hline $\operatorname{ADG}\left(\mathrm{g} \mathrm{d}^{-1}\right)$ & $890.01_{10.51}^{\mathrm{a}}$ & $841.20_{9.87}^{\mathrm{b}}$ \\
\hline ADFI $\left(\mathrm{kg} \mathrm{d}^{-1}\right)$ & $2.27_{0.01}^{\mathrm{a}}$ & $2.21_{0.01}^{\mathrm{b}}$ \\
\hline FCR $\left(\mathrm{kg} \mathrm{kg}^{-1}\right)$ & $2.54_{0.02}$ & $2.59_{0.02}$ \\
\hline \multicolumn{3}{|l|}{ Carcass traits } \\
\hline $\mathrm{HCW}^{2}(\mathrm{~kg})$ & $91.08_{018}^{\mathrm{a}}$ & $89.83_{017}^{\mathrm{b}}$ \\
\hline $\mathrm{LM}^{3}(\%)$ & $59.75_{0.07}^{\mathrm{a}}$ & $60.40_{0.06}^{\mathrm{b}}$ \\
\hline $\mathrm{LD}^{3}(\mathrm{~mm})$ & $62.51_{0.09}^{\mathrm{a}}$ & $66.87_{0.09}^{\mathrm{b}}$ \\
\hline $\mathrm{FT}^{3}(\mathrm{~mm})$ & $13.99_{0.05}$ & $13.93_{0.05}$ \\
\hline $\mathrm{BE}^{3}(\mathrm{~kg})$ & $13.18_{002}^{\mathrm{a}}$ & $12.84_{0}^{\mathrm{b}}$ \\
\hline $\operatorname{BLM}^{3}(\%)$ & $57.27_{0.09}^{\mathrm{a}}$ & $58.10_{0.08}^{\mathrm{b}}$ \\
\hline $\mathrm{BH}^{3}(\mathrm{~kg})$ & $17.83_{0.02}^{\mathrm{a}}$ & $17.97_{0.02}^{\mathrm{b}}$ \\
\hline $\mathrm{LO}^{3}(\mathrm{~kg})$ & $10.92_{0.01}^{\mathrm{a}}$ & $11.16_{0.01}^{\mathrm{b}}$ \\
\hline $\mathrm{BLO}^{3}(\mathrm{~kg})$ & $6.82_{0.01}^{\mathrm{a}}$ & $7.12_{0.01}^{\mathrm{b}}$ \\
\hline $\mathrm{BSH}^{3}(\mathrm{~kg})$ & $8.60_{0.01}^{\mathrm{a} .01}$ & $8.68_{0.01}^{\mathrm{b}}$ \\
\hline \multicolumn{3}{|l|}{ Meat quality } \\
\hline $\mathrm{pH}_{45 \text { min }}^{3}$ & $6.51_{0.02}$ & $6.54_{0.02}$ \\
\hline $\mathrm{pH}_{24 \mathrm{~h}}^{3}$ & $5.47_{0.01}^{\mathrm{a}}$ & $5.43_{0.01}^{\mathrm{b}}$ \\
\hline
\end{tabular}

${ }^{1}$ Initial age adjusted to $72 \mathrm{~d} .{ }^{2}$ Slaughter age adjusted to 173 d. ${ }^{3} \mathrm{HCW}$ adjusted to $91 \mathrm{~kg}$. ${ }^{\text {a-b }}$ Values within a row with different superscripts differ significantly.

ment with finding of Hermesch et al. (2000). Additionally, a higher ADFI is linked with a poorer feed efficiency (Godinho et al., 2018a). Feed efficiency was equal for both lines $(p=0.179)$, which indicates comparable energy demands for maintenance. But in consideration of the difference in carcass composition it is to expect that the protein requirements differ between the sire lines. In particular, it is well known that growth-emphasized genotypes had a higher protein requirement and need a closer energy-protein ratio to exploit their growth potential (Emmans and Kyriazakis, 1997; Quiniou et al., 1996; Whittemore et al., 2001). Metabolic differences in protein disposition and energy metabolisms between the sire lines could be an explanation for the findings of the current study. Saintilan et al. (2015) reported $13 \%$ higher average digestible lysine requirements for the $25 \%$ most efficient pigs compared to the $25 \%$ least efficient pigs. Furthermore, the effect of sire line might be attributable to differences in additive genetic variance and thus heritability between lines, leading to different breeding progress. It can be assumed that the genetic progress realized under the diet used on the test farm is not completely transferable when 
Table 5. LSQ mean (with SE as index) of the significant interactions between sire line and sex for growth traits and carcass traits.

\begin{tabular}{|c|c|c|c|c|}
\hline & \multicolumn{2}{|c|}{ Sire line A } & \multicolumn{2}{|c|}{ Sire line B } \\
\hline & Male & Female & Male & Female \\
\hline \multicolumn{5}{|l|}{ Growth traits } \\
\hline $\begin{array}{l}\mathrm{ADG}_{\text {net }}\left(\mathrm{g} \mathrm{d}^{-1}\right) \\
\operatorname{ADG}\left(\mathrm{g} \mathrm{d}^{-1}\right) \\
\operatorname{ADFI}\left(\mathrm{kg} \mathrm{d}^{-1}\right)\end{array}$ & $\begin{array}{r}536.00_{3.90}^{\mathrm{a}} \\
893.21_{14.9}^{\mathrm{a}} \\
2.31_{0.02}^{\mathrm{a}}\end{array}$ & $\begin{array}{r}526.72_{3.97}^{\mathrm{a}} \\
886.79_{14.4}^{\mathrm{a}} \\
2.21_{0.02}^{\mathrm{b}}\end{array}$ & $\begin{array}{r}528.69_{3.79}^{\mathrm{a}} \\
873.54_{13.0}^{\mathrm{a}} \\
2.31_{0.02}^{\mathrm{a}}\end{array}$ & $\begin{array}{r}499.49_{3.88}^{\mathrm{b}} \\
808.87_{15.3}^{\mathrm{b}} \\
2.11_{0.02}^{\mathrm{c}}\end{array}$ \\
\hline \multicolumn{5}{|l|}{ Carcass traits } \\
\hline $\begin{array}{l}\mathrm{HCW}^{1}(\mathrm{~kg}) \\
\mathrm{LM}^{2}(\%) \\
\mathrm{LD}^{2}(\mathrm{~mm}) \\
\mathrm{FT}^{2}(\mathrm{~mm}) \\
\mathrm{BE}^{2}(\mathrm{~kg}) \\
\mathrm{BLM}^{2}(\%) \\
\mathrm{BH}^{2}(\mathrm{~kg}) \\
\mathrm{LO}^{2}(\mathrm{~kg}) \\
\mathrm{BLO}^{2}(\mathrm{~kg}) \\
\mathrm{BSH}^{2}(\mathrm{~kg})\end{array}$ & $\begin{array}{c}91.66_{0.26}^{\mathrm{a}} \\
58.49_{0.09}^{\mathrm{a}} \\
61.50_{0.13}^{\mathrm{a}} \\
14.81_{0.07}^{\mathrm{a}} \\
13.34_{0.02}^{\mathrm{a}} \\
55.67_{0.12}^{\mathrm{a}} \\
17.05_{0.03}^{\mathrm{a}} \\
10.75_{0.01}^{\mathrm{a}} \\
6.66_{0.01}^{\mathrm{a}} \\
8.50_{0.01}^{\mathrm{a}}\end{array}$ & $\begin{array}{c}90.52_{0.26}^{\mathrm{b}} \\
61.01_{0.09}^{\mathrm{b}} \\
63.48_{0.13}^{\mathrm{b}} \\
13.07_{0.07}^{\mathrm{b}} \\
13.02_{0.02}^{\mathrm{b}} \\
58.88_{0.12}^{\mathrm{b}} \\
17.70_{0.03}^{\mathrm{b}} \\
11.08_{0.01}^{\mathrm{b}} \\
6.99_{0.01}^{\mathrm{b}} \\
8.71_{0.01}^{\mathrm{b}}\end{array}$ & $\begin{array}{c}91.31_{0.24}^{\mathrm{ab}} \\
58.64_{0.09}^{\mathrm{a}} \\
65.40_{0.13}^{\mathrm{c}} \\
15.17_{0.07}^{\mathrm{a}} \\
13.07_{0.02}^{\mathrm{bc}} \\
55.78_{0.11}^{\mathrm{a}} \\
17.52_{0.03}^{\mathrm{c}} \\
10.92_{0.01}^{\mathrm{c}} \\
6.90_{0.01}^{\mathrm{c}} \\
8.51_{0.01}^{\mathrm{a}}\end{array}$ & $\begin{array}{c}88.35_{0.25}^{\mathrm{c}} \\
62.17_{0.09}^{\mathrm{c}} .09 \\
68.31_{0.13}^{\mathrm{d}} .00 \\
12.70_{0.07}^{\mathrm{c}} \\
12.60_{0.02}^{\mathrm{d}} \\
60.41_{0.12}^{\mathrm{c}} \\
18.43_{0.03}^{\mathrm{d}} \\
11.40_{0.01}^{\mathrm{d}} \\
7.35_{0.01}^{\mathrm{d}} \\
8.83_{0.01}^{\mathrm{c}}\end{array}$ \\
\hline
\end{tabular}

${ }^{1}$ Slaughter age adjusted to $173 \mathrm{~d} .{ }^{2} \mathrm{HCW}$ adjusted to $91 \mathrm{~kg} .{ }^{\mathrm{a}-\mathrm{d}}$ Values within a row with different superscripts differ significantly $(p<0.01)$.

using other diets, like in the current trial. In this context, Godinho et al. (2018b, c) reported impairment of lipid disposition and residual energy intake in pigs on different diets due to genotype by feed interactions, which could be a reason for the observed differences in growth performance and carcass value. Moreover, findings of Škorput and Luković (2018) suggest a range of additive genetic variance for ADG from $586.09 \pm 55.73 \mathrm{~g} \mathrm{~d}^{-1}$ in the Large White population to $1190.03 \pm 139 \mathrm{~g} \mathrm{~d}^{-1}$ in Piétrain populations.

As expected, heavier HCW was detected for sire line A due to faster growth rate. This is in line with Miar et al. (2014), who reported a strong correlation between growth rate and $\mathrm{HCW}(r=0.75 \pm 0.28 ; p \leq 0.05)$. According to Dufrasne et al. (2013) and Zumbach et al. (2007), with $2.03 \%$ and $6.7 \%$, respectively, sire line explained only low proportions of genetic variance for final live body weight. It is even known that heritability ranges between 0.15 and 0.39 depending on the estimation method and the population (Dufrasne et al., 2014; Fragomeni et al., 2016; Holl et al., 2008; Khanal et al., 2019; Miar et al., 2014). Against expectations, the FT was equal in both sire lines. However, the ratio of LD and FT in consideration of sire line suggested a lower FT, which is resulting from a higher lean growth potential in pigs sired by line B. Additionally, the current results are in line with van Wijk et al. (2005), who reported that selection for higher growth led to effects decreasing most primal and sub-primal cut weights. Selection for leanness in Piétrain sire has resulted in reduced feed intake capacity (Labroue et al., 1999; Lean et al., 1972). Hence, the leaner carcass with lighter $\mathrm{BE}$ is linked to a higher muscle growth potential of pigs sired by sire line B. Findings of Correa et al. (2008)
Table 6. LSQ mean (with SE as index) of growth and carcass traits according to the birth weight classes $\left(\mathrm{BW}_{\mathrm{Q}}\right)$.

\begin{tabular}{|c|c|c|c|}
\hline & \multicolumn{3}{|c|}{$\mathrm{BW}_{\mathrm{Q}}$} \\
\hline & $\mathrm{Q}_{1}$ & $\mathrm{Q}_{2}$ & $\mathrm{Q}_{3}$ \\
\hline \multicolumn{4}{|l|}{ Growth trait } \\
\hline $\mathrm{ADG}_{\text {net }}\left(\mathrm{g} \mathrm{d}^{-1}\right)$ & $499.47_{2.54}^{\mathrm{a}}$ & $527.40_{2.39}^{\mathrm{b}}$ & $541.76_{2.54}^{\mathrm{c}}$ \\
\hline \multicolumn{4}{|l|}{ Carcass traits } \\
\hline $\mathrm{HCW}^{1}(\mathrm{~kg})$ & $87.23_{0.25}^{\mathrm{a}}$ & $91.89_{0.17}^{\mathrm{b}}$ & $93.05_{0.25}^{\mathrm{c}}$ \\
\hline $\mathrm{LM}^{2}(\%)$ & $59.00_{0.09}^{\mathrm{a}}$ & $60.26_{0.06}^{\mathrm{b}}$ & $60.97_{0.09}^{\mathrm{c}}$ \\
\hline $\mathrm{LD}^{2}(\mathrm{~mm})$ & $63.70_{0.13}^{\mathrm{a}}$ & $64.89_{0.09}^{\mathrm{b}}$ & $65.49_{0.13}^{\mathrm{c}}$ \\
\hline $\mathrm{FT}^{2}(\mathrm{~mm})$ & $14.78_{0.07}^{\mathrm{a}}$ & $13.82_{0.05}^{\mathrm{b}}$ & $13.29_{0.07}^{\mathrm{c}}$ \\
\hline $\mathrm{BE}^{2}(\mathrm{~kg})$ & $13.26_{0.02}^{\mathrm{a}}$ & $12.96_{0.01}^{\mathrm{b}}$ & $12.79_{0.02}^{\mathrm{c}}$ \\
\hline $\mathrm{BLM}^{2}(\%)$ & $56.31_{0.12}^{0.02}$ & $57.93_{0.08}^{\mathrm{b}}$ & $58.81_{0.12}^{\mathrm{c}}$ \\
\hline $\mathrm{BH}^{2}(\mathrm{~kg})$ & $17.33_{0.03}^{\mathrm{a}}$ & $17.75_{0.02}^{\mathrm{b}}$ & $17.95_{0.03}^{\mathrm{c}}$ \\
\hline $\mathrm{LO}^{2}(\mathrm{~kg})$ & $10.88_{0.01}^{\mathrm{a}}$ & $11.07_{0.009}^{\mathrm{b}}$ & $11.17_{0.01}^{\mathrm{c}}$ \\
\hline $\mathrm{BLO}^{2}(\mathrm{~kg})$ & $6.81_{0.01}^{\mathrm{a}}$ & $7.00_{0.009}^{\mathrm{b}}$ & $7.10_{0.01}^{\mathrm{c}}$ \\
\hline $\mathrm{BSH}^{2}(\mathrm{~kg})$ & $8.52_{0.01}^{\mathrm{a}}$ & $8.66_{0.007}^{\mathrm{b}}$ & $8.73_{0.01}^{\mathrm{c}}$ \\
\hline
\end{tabular}

${ }^{1}$ Slaughter age adjusted to $173 \mathrm{~d}$. ${ }^{2} \mathrm{HCW}$ adjusted to $91 \mathrm{~kg}$. ${ }^{\mathrm{a}-\mathrm{c}}$ Values within a row with different superscripts differ significantly $(p<0.001)$.

and Lowell et al. (2019) support these results. However, as discussed above, a higher protein requirement in combination with an inappropriate energy level could also be an explanation for the poorer carcass value of the offspring sired by line A. Furthermore, based on a nonlinear association between daily growth and muscle growth, pigs with more than $60 \%$ lean meat tend to grow slower (Argemí-Armengol et al., 2019), which is consistent with the results of the current study.

Males reached a higher $\mathrm{BW}_{\text {final }}$ at the same slaughtering age as compared to females, which is linked to $35.5 \mathrm{~g} \mathrm{~d}^{-1}$ faster growth rate. Additionally, FCR was better by 0.11 in females, which agrees with the findings of Serrano et al. (2008) and Renaudeau et al. (2006), but is in contrast to Lee et al. (2019) and Peinado et al. (2008). The poorer FCR of males is related to the moderately faster growth rate and the $160 \mathrm{~g} \mathrm{~d}^{-1}$ higher ADFI. The $\mathrm{PD}_{\max }$ is the point of maximum protein accretion of a pig and up to this plateau, protein growth responds linearly to feed intake (Campbell et al., 1985; Whittemore and Fawcett, 1976). Consequently, pigs with a high feed intake reach this point earlier and tend to accumulate fat tissue as the $\mathrm{PD}_{\max }$ is exceeded (Lewis and Lee Southern, 2000; Tullis, 1982). This might explain the fatter carcasses of male pigs in the current study. Generally, it is expected that females have a higher ratio of protein accretion relative to lipid accretion, and this is in agreement with Noblet et al. (1999), Schinckel et al. (2008) and Serrano et al. (2008). Further insight into biological differences between the sire lines can be drawn from the significant interactions between sire line and sex, which were also found 
by Lowell et al. (2019) and Morales et al. (2011). Generally, these interactions clearly indicate that pigs sired by line A grew faster than pigs sired by line B and that pigs from sire line B showed a leaner carcass with heavier primal cuts compared to the other sire line. Similar growth rate $\left(\mathrm{ADG}_{\text {net }}\right.$, ADG) of males and females sired by line A suggested a more homogenous growth performance in offspring of this sire line. However, the differences in carcass traits between males and females were smaller in sire line A and supported the homogenous growth of this line. Moreover, only females of sire line $\mathrm{B}$ differed in growth rate $\left(\mathrm{ADG}_{\text {net }}, \mathrm{ADG}\right)$ compared to all other variations, which is explained by the significant lower ADFI in comparison with males regardless of the sire line. Neither a difference in growth rate $\left(\mathrm{ADG}_{\mathrm{net}}, \mathrm{ADG}\right)$ nor in ADFI between both male groups was detected, but females differed significantly. Regarding a different protein requirement between the sire lines, an explanation could be that the females sired by line A better exploited their growth potential compared to the males of the same sire line, despite the fact that the energy-protein ratio does not seem to be optimal for this genotype. Findings by Chen et al. (1999) and Hansen and Lewis (1993) indicated different responses with deficient or excessive protein intake between castrated males and females, and Martins et al. (2012) reported differences in protein requirements between different genotypes. Hence, a better adaptability to the available level of protein and energy content of females sired by line A in contrast to the males of the same genotype is an explanation for the interactions between sire line and sex regarding the growth rate.

Regarding the birth weight, the $\mathrm{ADG}_{\text {net }}$ increased with increasing $\mathrm{BW}_{\mathrm{Q}}$ and indicated that heavier birth weight pigs grow faster with improving subsequent performance, which is in line with Fix et al. (2010) and Vázquez-Gómez et al. (2020). However, Douglas et al. (2013) reported that birth weight had less impact on subsequent growth performance compared to weaning weight or initial weight in the finisher barn. Nevertheless, in the current study fatter carcasses in pigs of the $\mathrm{BW}_{\mathrm{Q} 1}$ and $\mathrm{BW}_{\mathrm{Q} 2}$ compared to heavier birth weight pigs of $\mathrm{BW}_{\mathrm{Q} 3}$ were detected and are in agreement with the findings of Nissen et al. (2004) and Rehfeldt and Kuhn (2006). A decreasing proportion of ham, loin and belly in the lightest birth weight classes suggested disadvantages in growth performance, in terms of less ADG, lower ADFI and a poorer FCR. These findings were generally in line with Gondret et al. (2005) and Rehfeldt et al. (2008). However, lower belly weight in pigs with higher birth weight may be explained by further selection for higher proportion of lean meat. In agreement with Kim et al. (2017), stronger selection for lean meat is linked to less fat disposition in belly muscle and leads to lower belly weight. Moreover, no interactions between sire line and $\mathrm{BW}_{\mathrm{Q}}$ indicated that offspring of both sire lines show the same biological relation between birth weight and carcass traits, except for LD. Hence, similar $\mathrm{LD}$ between the $\mathrm{BW}_{\mathrm{Q} 2}$ and the $\mathrm{BW}_{\mathrm{Q} 3}$ class in sire line $\mathrm{A}(p \geq 0.05)$ indicated that an additional gain of $\geq 1.70 \mathrm{~kg}$ birth weight would not lead to a further meat gain within this genetic line. Consequently, biological limit in this trait seems to be reached, and further selection in sire line $\mathrm{A}$ on birth weight would not increase the LD. According to Beaulieu et al. (2010) and Gondret et al. (2005), it is not unexpected that carcass leanness is not primarily influenced by birth weight. Other factors, such as initial and final body weight, the level of feed intake, growth rate, feed processing and delivery, and genetic potential were also involved (Patience et al., 2015). This interaction supported a difference in protein and energy metabolism between the sire lines.

Based on the findings of Latorre et al. (2003), Lloveras et al. (2008), Lowell et al. (2019) and Miller et al. (2000), $\mathrm{pH}$ values in this study were generally within normal range. Unlike Miller et al. (2000) and Latorre et al. (2003) but in agreement with Kim et al. (2017) and Fecke (2013), $\mathrm{pH}_{45}$ min was not affected by genotype. However, pigs sired by sire line $\mathrm{B}$ showed lower $\mathrm{pH}_{24} \mathrm{~h}$, indicating poorer meat quality. Drip losses are moderately to strongly negatively correlated with the texture of loin $(-0.23 \pm 0.06)$, belly weight $(-0.46 \pm 0.14)$ and $\mathrm{pH}_{24} \mathrm{~h}(-0.99 \pm 0.49)(p \leq 0.05)$ (Miar et al., 2014). Similar results were reported by Kim et al. (2017) and Otto et al. (2006). Consequently, poorer water retention capacity among offspring of sire line B seems likely, and the leaner carcasses of this offspring back up this result. It suggests that higher leanness in line B and in females means poorer meat quality.

\section{Conclusions}

This research confirms differences in growth performance and carcass characteristics between crossbreeds of two different sire lines. Pigs sired by line A grow faster and had higher ADFI and the same FCR compared to offspring of line $B$. This resulted in a fatter carcass and heavier belly weights, which indicated a better meat quality due to a higher $\mathrm{pH}_{24} \mathrm{~h}$ in crossbreeds sired by line A. Leaner carcasses with heavier primal cuts were detected at offspring of line B and at heavier birth weight pigs. Males grew faster and reached a heavier but also fatter carcass. Regardless of sire line, piglets with heavier birth weight were leaner and had heavier primal and boneless primal weights. Except for LD, no interactions between sire line and $\mathrm{BW}_{\mathrm{Q}}$ were detected, indicating subsequent growth was equal in both lines, depending on birth weight. The detected interaction for LD between sire line and $\mathrm{BW}_{\mathrm{Q}}$ as well as sire line by sex interactions indicated different protein requirements between the genotypes. In conclusion, in a fatting production system, paternal line A is preferable if a producer wishes to increase the number of fatting pigs per fattening place and year. Additionally, in the dam line, emphasis should be put on leanness. Breeding with paternal line B is a good option for a finisher producer if the goal is to increase leanness and carcass primal cuts. 
Data availability. All necessary data are provided within the article.

Author contributions. KE and JT wrote, edited and revised the paper. KE and NM designed the experiment, and KE carried it out. $\mathrm{KE}, \mathrm{NM}, \mathrm{RW}$ and JT reviewed and approved the final paper.

Competing interests. The authors declare that they have no conflict of interest.

Acknowledgements. The authors would like to thank the farm staff for their support in data recording.

Financial support. This open-access publication was funded by the University of Göttingen.

Review statement. This paper was edited by Steffen Maak and reviewed by Jörn Bennewitz and one anonymous referee.

\section{References}

Argemí-Armengol, I., Villalba, D., Ripoll, G., and ÁlvarezRodríguez, J.: Genetic but not lean grade impact on growth, carcass traits and pork quality under organic husbandry, Livest. Sci., 227, 75-81, https://doi.org/10.1016/j.livsci.2019.07.001, 2019.

Aymerich, P., Gasa, J., Bonet, J., Coma, J., and Solà-Oriol, D.: The effects of sire line, sex, weight and marketing day on carcass fatness of non-castrated pigs, Livest. Sci., 228, 25-30, https://doi.org/10.1016/j.livsci.2019.07.021, 2019.

Beaulieu, A. D., Aalhus, J. L., Williams, N. H., and Patience, J. F.: Impact of piglet birth weight, birth order, and litter size on subsequent growth performance, carcass quality, muscle composition, and eating quality of pork, J. Anim. Sci., 88, 2767-2778, https://doi.org/10.2527/jas.2009-2222, 2010.

BMEL: Bundesministerium für Ernährung und Landwirtschaft, Anerkannte Zuchtunternehmen in Deutschland und der EU, available at: https://tgrdeu.genres.de/ veroeffentlichungvoninformationengemaesstierzuchtrecht/ zuechtervereinigungen, last access: 27 December 2019.

Cámara, L., Berrocoso, J. D., Coma, J., López-Bote, C. J., and Mateos, G. G.: Growth performance and carcass quality of crossbreds pigs from two Piétrain sire lines fed isoproteic diets varying in energy concentration, Meat Sci., 114, 69-74, https://doi.org/10.1016/j.meatsci.2015.12.013, 2016.

Campbell, R. G., Taverner, M. R., and Curic, D. M.: Effects of sex and energy intake between 48 and $90 \mathrm{~kg}$ live weight on protein deposition in growing pigs, Anim. Sci., 40, 497-503, https://doi.org/10.1017/S0003356100040198, 1985.

Chen, H.-Y., Lewis, A. J., Miller, P. S., and Yen, J. T.: The effect of excess protein on growth performance and protein metabolism of finishing barrows and gilts, J. Anim. Sci., 77, 3238-3247, https://doi.org/10.2527/1999.77123238x, 1999.
Cilla, I., Altarriba, J., Guerrero, L., Gispert, M., Martínez, L., Moreno, C., Beltrán, J. A., Guàrdia, M. D., Diestre, A., Arnau, J., and Roncalés, P.: Effect of different Duroc line sires on carcass composition, meat quality and dry-cured ham acceptability, Meat Sci., 72, 252-260, https://doi.org/10.1016/j.meatsci.2005.07.010, 2006.

Correa, J. A., Gariépy, C., Marcoux, M., and Faucitano, L.: Effects of growth rate, sex and slaughter weight on fat characteristics of pork bellies, Meat Sci., 80, 550-554, https://doi.org/10.1016/j.meatsci.2007.12.018, 2008.

De Cuyper, C., Tanghe, S., Janssens, S., Van den Broeke, A., Van Meensel, J., Aluwé, M., Ampe, B., Buys, N., and Millet, S.: The effect of Piétrain sire on the performance of the progeny of two commercial dam breeds: a pig intervention study, Animal, 1-8, https://doi.org/10.1017/S1751731119000429, 2019.

Dodenhoff, J., Sinz, E., Helmreich, S. and Obermaier, S.: Neue Merkmale in der Schweinezucht und neue Wege in der Datenerfassung, Vortrag der LfL-Jahrestagung 2019, Schweinehaltung, neue Herausforderungen meistern!, 27.11.2019 in Ergolding, Tagungsband, ISSN 1611-4159, 19-24, 2019.

Douglas, S. L., Edwards, S. A., Sutcliffe, E., Knap, P. W., and Kyriazakis, I.: Identification of risk factors associated with poor lifetime growth performance in pigs, J. Anim. Sci., 91, 4123-4132, https://doi.org/10.2527/jas.2012-5915, 2013.

Dufrasne, M., Misztal, I., Tsuruta, S., Holl, J., Gray, K. A., and Gengler, N.: Estimation of genetic parameters for birth weight, preweaning mortality, and hot carcass weight of crossbred pigs, J. Anim. Sci., 91, 5565-5571, https://doi.org/10.2527/jas.20136684, 2013.

Dufrasne, M., Misztal, I., Tsuruta, S., Gengler, N., and Gray, K. A.: Genetic analysis of pig survival up to commercial weight in a crossbred population, Livest. Sci., 167, 19-24, https://doi.org/10.1016/j.livsci.2014.05.001, 2014.

Emmans, G. C. and Kyriazakis, I.: Models of pig growth: problems and proposed solutions, Livest. Prod. Sci., 51, 119-129, https://doi.org/10.1016/S0301-6226(97)00061-4, 1997.

Fecke, A.: Physiologische und genetische Einflüsse auf die Qualität von Schweinefleisch aus baden-württembergischen Gebrauchskreuzungen, Ph.D thesis, Univerersity Hohenheim, Germany, 222 pp., 2013.

Fix, J. S., Cassady, J. P., Herring, W. O., Holl, J. W., Culbertson, M. S., and See, M. T.: Effect of piglet birth weight on body weight, growth, backfat, and longissimus muscle area of commercial market swine, Livest. Sci., 127, 51-59, https://doi.org/10.1016/j.livsci.2009.08.007, 2010.

Fragomeni, B. O., Lourenco, D. A. L., Tsuruta, S., Bradford, H. L., Gray, K. A., Huang, Y., and Misztal, I.: Using single-step genomic best linear unbiased predictor to enhance the mitigation of seasonal losses due to heat stress in pigs, J. Anim. Sci., 94, 5004-5013, https://doi.org/10.2527/jas.2016-0820, 2016.

Franco, D., Vazquez, J. A., and Lorenzo, J. M.: Growth performance, carcass and meat quality of the Celta pig crossbred with Duroc and Landrance genotypes, Meat Sci., 96, 195-202, https://doi.org/10.1016/j.meatsci.2013.06.024, 2014.

García-Casco, J. M., Fernández, A., Rodríguez, M. C., and Silió, L.: Heterosis for litter size and growth in crosses of four strains of Iberian pig, Livest. Sci., 147, 1-8, https://doi.org/10.1016/j.livsci.2012.03.005, 2012. 
Gilleland, H. L., Detweiler, R., Azain, M. J., and Pringle, D.: Effects of Sire Line, Slaughter Weight, and Gender on Pork Quality and Yield Characteristics, Meat and Muscle Biology, 1, p. 88, https://doi.org/10.22.1751/rmc2017.083, 2019.

Godinho, R. M., Bergsma, R., Silva, F. F., Sevillano, C. A., Knol, E. F., Lopes, M. S., Lopes, P. S., Bastiaansen, J. W. M., and Guimarães, S. E. F.: Genetic correlations between feed efficiency traits, and growth performance and carcass traits in purebred and crossbred pigs, J. Anim. Sci., 96, 817-829, https://doi.org/10.1093/jas/skx011, 2018a.

Godinho, R. M., Bastiaansen, J. W. M., Sevillano, C. A., Silva, F. F., Guimarães, S. E. F., and Bergsma, R.: Genotype by feed interaction for feed efficiency and growth performance traits in pigs, J. Anim. Sci., 96, 4125-4135, https://doi.org/10.1093/jas/sky304, 2018b.

Godinho, R. M., Bergsma, R., Sevillano, C. A., Silva, F. F., and Guimarães, S. E. F.: Genotype by feed interaction in grower-finisher pigs fed different diets, Conference Paper, World Congress on Genetics Applied to Livestock Production, 5 pp., 2018c.

Gondret, F., Lefaucheur, L., Louveau, I., Lebret, B., Pichodo, X., and Le Cozler, Y.: Influence of piglet birth weight on postnatal growth performance, tissue lipogenic capacity and muscle histological traits at market weight, Livest. Prod. Sci., 93, 137-146, https://doi.org/10.1016/j.livprodsci.2004.09.009, 2005.

Hansen, B. C. and Lewis, A. J.: Effects of dietary protein concentration (corn:soybean meal ratio) on the performance and carcass characteristics of growing boars, barrows, and gilts: mathematical descriptions, J. Anim. Sci., 71, 2122-2132, https://doi.org/10.2527/1993.7182122x, 1993.

Hermesch, S., Luxford, B. G., and Graser, H.-U.: Genetic parameters for lean meat yield, meat quality, reproduction and feed efficiency traits for Australian pigs: 2. Genetic relationships between production, carcase and meat quality traits, Livest. Prod. Sci., 65, 249-259, https://doi.org/10.1016/S0301-6226(00)00151-2, 2000.

Holl, J. W., Rohrer, G. A., Shackelford, S. D., Wheeler, T. L., and Koohmaraie, M.: Estimates of genetic parameters for kyphosis in two crossbred swine populations, J. Anim. Sci., 86, 1765-1769, https://doi.org/10.2527/jas.2007-0628, 2008.

Katoele, J., Knol, E. F., and van der Lende, T.: Effect of inbreeding and heterosis on piglet survival in a large commercial dataset, Montpellier, France, 4 pp., 2002.

Kavlak, A. T. and Uimari, P.: Estimation of heritability of feeding behaviour traits and their correlation with production traits in Finnish Yorkshire pigs, J. Anim. Breed Genet., 136, 484-494, https://doi.org/10.1111/jbg.12408, 2019.

Khanal, P., Maltecca, C., Schwab, C., Gray, K., and Tiezzi, F.: Genetic parameters of meat quality, carcass composition, and growth traits in commercial swine, J. Anim. Sci., 97, 3669-3683, https://doi.org/10.1093/jas/skz247, 2019.

Kim, J.-M., Lee, S.-H., and Ryu, Y.-C.: Comparisons of meat quality and musclebre characteristics on multiple pig breeds and sexes using principal component analysis, Anim. Prod. Sci., 58, 2091, https://doi.org/10.1071/AN16223, 2017.

Labroue, F., Guéblez, R., and Sellier, P.: Genetic parameters of feeding behaviour and performance traits in group-housed Large White and French Landrace growing pigs, Genet. Sel. Evol., 29, 451, https://doi.org/10.1186/1297-9686-29-4-451, 1997.
Labroue, F., Guéblez, R., Meunier-Salaün, M.-C., and Sellier, P.: Feed intake behaviour of group-housed Piétrain and Large White growing pigs, Ann. Zootech., 48, 247-261, https://doi.org/10.1051/animres:19990402, 1999.

Latorre, M. A., Lázaro, R., Gracia, M. I., Nieto, M., and Mateos, G. G.: Effect of sex and terminal sire genotype on performance, carcass characteristics, and meat quality of pigs slaughtered at $117 \mathrm{~kg}$ body weight, Meat Sci., 65, 1369-1377, https://doi.org/10.1016/S0309-1740(03)00059-7, 2003.

Lean, I. J., Curran, M. K., Duckworth, J. E., and Holmes, W. Studies on Belgian Piétrain pigs 1. A comparison of Piétrain, Landrace and Piétrain Landrace crosses in growth, carcass characteristics and meat quality, Anim. Sci., 15, 1-9, https://doi.org/10.1017/S0003356100011156, 1972.

Lee, J. H., Song, M. H., Yun, W., Liu, S. D., Lee, C. H., Oh, H. J., An, J. S., Yu, D. J., Kim, H. B., and Cho, J. H.: Influence of season of birth, sex and paternal line on growth performance and carcass traits in pigs, SA J. An. Sci., 49, 371, https://doi.org/10.4314/sajas.v49i2.16, 2019.

Lewis, A. J. and Lee Southern, L.: Swine Nutrition, CRC Press, Florida, 1032 pp., 2000.

Lloveras, M. R., Goenaga, P. R., Irurueta, M., Carduza, F., Grigioni, G., García, P. T., and Améndola, A.: Meat quality traits of commercial hybrid pigs in Argentina, Meat Sci., 79, 458-462, https://doi.org/10.1016/j.meatsci.2007.10.033, 2008.

Lowell, J. E., Schunke, E. D., Harsh, B. N., Bryan, E. E., Stahl, C. A., Dilger, A. C., and Boler, D. D.: Growth performance, carcass characteristics, fresh belly quality, and commercial bacon slicing yields of growing-finishing pigs from sire lines intended for different industry applications, Meat Sci., 154, 96108, https://doi.org/10.1016/j.meatsci.2019.04.010, 2019.

Luo, J., Shen, L., Tan, Z., Cheng, X., Yang, D., Fan, Y., Yang, Q., Ma, J., Tang, Q., Jiang, A., Jiang, D., Tang, G., Jiang, Y., Li, X., Yang, R., Zhang, S., and Zhu, L.: Comparison reproductive, growth performance, carcass and meat quality of Liangshan pig crossbred with Duroc and Berkshire genotypes and heterosis prediction, Livest. Sci., 212, 61-68, https://doi.org/10.1016/j.livsci.2017.09.010, 2018.

Martins, A. P., Lopes, P. A., Madeira, M. S., Martins, S. V., Santos, N. C., Moura, T. F., Prates, J. A. M., and Soveral, G.: Differences in lipid deposition and adipose membrane biophysical properties from lean and obese pigs under dietary protein restriction, Biochem. Biophys. Res. Commun., 423, 170-175, https://doi.org/10.1016/j.bbrc.2012.05.108, 2012.

Miar, Y., Plastow, G., Bruce, H., Moore, S., Manafiazar, G., Kemp, R., Charagu, P., Huisman, A., Haandel, B. van, Zhang, C., McKay, R., and Wang, Z.: Genetic and Phenotypic Correlations between Performance Traits with Meat Quality and Carcass Characteristics in Commercial Crossbred Pigs, PLOS ONE, 9, e110105, https://doi.org/10.1371/journal.pone.0110105, 2014.

Miller, K. D., Ellis, M., McKeith, F. K., and Wilson, E. R.: Influence of sire line and halothane genotype on growth performance, carcass characteristics, and meat quality in pigs, Can. J. Anim. Sci., 80, 319-327, https://doi.org/10.4141/A99-074, 2000.

Morales, J. I., Cámara, L., Berrocoso, J. D., López, J. P., Mateos, G. G., and Serrano, M. P.: Influence of sex and castration on growth performance and carcass quality of crossbred pigs from 2 Large White sire lines1, J. Anim. Sci., 89, 3481-3489, https://doi.org/10.2527/jas.2010-3357, 2011. 
Nissen, P. M., Jorgensen, P. F., and Oksbjerg, N.: Withinlitter variation in muscle fiber characteristics, pig performance, and meat quality traits, J. Anim. Sci., 82, 414-421, https://doi.org/10.1093/ansci/82.2.414, 2004.

Noblet, J., Karege, C., Dubois, S., and van Milgen, J.: Metabolic utilization of energy and maintenance requirements in growing pigs: effects of sex and genotype, J. Anim. Sci., 77, 1208, https://doi.org/10.2527/1999.7751208x, 1999.

Otto, G., Roehe, R., Looft, H., Thoelking, L., Henning, M., Plastow, G. S., and Kalm, E.: Drip loss of case-ready meat and of premium cuts and their associations with earlier measured sample drip loss, meat quality and carcass traits in pigs, Meat Sci., 72, 680-687, https://doi.org/10.1016/j.meatsci.2005.10.001, 2006.

Patience, J. F., Rossoni-Serão, M. C., and Gutiérrez, N. A.: A review of feed efficiency in swine: biology and application, J. Anim. Sci. Biotech., 6, 33, https://doi.org/10.1186/s40104-015-0031-2, 2015.

Peinado, J., Medel, P., Fuentetaja, A., and Mateos, G. G.: Influence of sex and castration of females on growth performance and carcass and meat quality of heavy pigs destined for the dry-cured industry, J. Anim. Sci., 86, 1410-1417, https://doi.org/10.2527/jas.2006-807, 2008.

Quiniou, N., Noblet, J., and Dourmad, J.-Y.: Effect of energy intake on the performance of different types of pig from 45 to $100 \mathrm{~kg}$ body weight, 2. Tissue gain, Anim. Sci., 63, 289-296, https://doi.org/10.1017/S1357729800014843, 1996.

Rehfeldt, C. and Kuhn, G.: Consequences of birth weight for postnatal growth performance and carcass quality in pigs as related to myogenesis, J. Anim. Sci., 84, 113-123, https://doi.org/10.2527/2006.8413_supplE113x 2006.

Rehfeldt, C., Tuchscherer, A., Hartung, M., and Kuhn, G.: A second look at the influence of birth weight on carcass and meat quality in pigs, Meat Sci., 78, 170-175, https://doi.org/10.1016/j.meatsci.2007.05.029, 2008.

Renaudeau, D., Giorgi, M., Silou, F., and Weisbecker, J. L.: Effect of Breed (Lean or Fat Pigs) and Sex on Performance and Feeding Behaviour of Group Housed Growing Pigs in a Tropical Climate, Asian Australas, J. Anim. Sci., 19, 593-600, https://doi.org/10.5713/ajas.2006.593, 2006.

Saintilan, R., Brossard, L., Vautier, B., Sellier, P., Bidanel, J., van Milgen, J., and Gilbert, H.: Phenotypic and genetic relationships between growth and feed intake curves and feed efficiency and amino acid requirements in the growing pig, Animal, 9, 18-27, https://doi.org/10.1017/S1751731114002171, 2015.

Schinckel, A. P., Mahan, D. C., Wiseman, T. G., and Einstein, M. E.: Impact of Alternative Energy Systems on the Estimated Feed Requirements of Pigs with Varying Lean and Fat Tissue Growth Rates When Fed Corn and Soybean Meal-Based Diets, Prof. Ani. Sci., 24, 198-207, https://doi.org/10.1532/S10807446(15)30841-X, 2008.
Serrano, M. P., Valencia, D. G., Nieto, M., Lázaro, R., and Mateos, G. G.: Influence of sex and terminal sire line on performance and carcass and meat quality of Iberian pigs reared under intensive production systems, Meat Sci., 78, 420-428, https://doi.org/10.1016/j.meatsci.2007.07.006, 2008.

Škorput, D. and Luković, Z.: Partition of genetic trend for daily gain by sex in Landrace, Large White, Piétrain, and Duroc pigs, Journal of Central European agriculture, 19, 648-657, https://doi.org/10.5513/JCEA01/19.3.2130, 2018.

TierSchIV: Verordnung zum Schutz von Tieren im Zusammenhang mit der Schlachtung oder Tötung und zur Durchführung der Verordnung (EG) Nr. 1099/2009 des Rates, available at: https://www.gesetze-im-internet.de/tierschlv_2013/ BJNR298200012.html, (last access: 3 September 2019), 2012.

Tullis, J. B.: Protein growth in pigs, Ph.D. thesis, University of Edinburgh, United Kingdom, 299 pp., 1982.

van Wijk, H. J., Arts, D. J. G., Matthews, J. O., Webster, M., Ducro, B. J., and Knol, E. F.: Genetic parameters for carcass composition and pork quality estimated in a commercial production chain, J. Anim. Sci., 83, 324-333, https://doi.org/10.2527/2005.832324x, 2005.

Vázquez-Gómez, M., García-Contreras, C., Astiz, S., TorresRovira, L., Fernández-Moya, E., Olivares, Á., Daza, A., Óvilo, C., González-Bulnes, A., and Isabel, B.: Piglet birthweight and sex affect growth performance and fatty acid composition in fatty pigs, Anim. Prod. Sci., 60, 573-583, https://doi.org/10.1071/AN18254, 2020.

Vermeulen, L., Van Beirendonck, S., Bulens, A., Van Thielen, J., and Driessen, B.: Sire line of pigs affects weaning weight, growth performance, and carcass characteristics of offspring, J. Anim. Sci., 94, 4360-4368, 2016.

Whittemore, C. T. and Fawcett, R. H.: Theoretical aspects of a flexible model to stimulate protein and lipid growth in pigs, Anim. Sci., 22, 87-96, https://doi.org/10.1017/S0003356100035455, 1976.

Whittemore, C. T., Green, D. M., and Knap, P. W.: Technical review of the energy and protein requirements of growing pigs: protein, Anim. Sci., 73, 363-373, https://doi.org/10.1017/S1357729800058331, 2001.

Zumbach, B., Misztal, I., Tsuruta, S., Holl, J., Herring, W., and Long, T.: Genetic correlations between two strains of Durocs and crossbreds from differing production environments for slaughter traits, J. Anim. Sci., 85, 901-908, https://doi.org/10.2527/jas.2006-499, 2007. 